\title{
Job insecurity and organizational citizenship behavior: The role of affective commitment
}

\author{
Debora Eflina Purba ${ }^{1}$, Fahri Muhammad ${ }^{2}$ \\ ${ }^{1,2}$ Faculty of Psychology, Universitas Indonesia, Indonesia \\ 1eflina@ui.ac.id; ${ }^{2}$ fmuhammad96@gmail.com
}

\section{ARTICLE INFO}

Article history

Received 10 December 2019

Revised 16 June 2020

Accepted 17 June 2020

Keywords

affective commitment

job insecurity

organizational citizenship behavior

\begin{abstract}
Previous research showed inconsistent findings in the relationship between job insecurity and OCB, indicating an underlying mechanism to occur between the variables. This study aimed to examine affective commitment as a mediator in the relationship between job insecurity and organizational citizenship behavior (OCB). Drawing on organizational identification theory, we took on the perspective of organizational concern motive and suggested affective commitment to mediate the job insecurity and OCB relationship. The study employs a correlational design with an accidental sampling technique. Participants of the study were employees of private and state-owned companies in Indonesia $(N=217)$. Data were analyzed on Hayes's PROCESS macro on SPSS statistic software. Results show a significantly negative relationship between job insecurity and OCB, significantly negative relationship between job insecurity and affective commitment relationship, and a significantly positive relationship between affective commitment and OCB. Furthermore, affective commitment is found to mediate the relationship between job insecurity and $\mathrm{OCB}$, confirming the organizational concern motive of $\mathrm{OCB}$ as a consequence of job insecurity. The study implies that organizations should eliminate job insecurity if possible, or design interventions to develop employee's oneness with the organization.
\end{abstract}

\section{Introduction}

Global economic condition nowadays has impacted uncertainty and competition in the business world (Organ et al., 2005). This situation is pushing companies to develop the ability to compete by having employees who are willing to do work above and beyond their main job to win the competition (Organ et al., 2005; N. P. Podsakoff et al., 2009). In other words, employees are expected to perform organizational citizenship behavior (OCB), actions intended to help other individuals, and the organization that is performed voluntarily by an employee. Previous empirical studies have identified positive consequences of OCB on an individual, group, and organizational performance. At the level of the individual, Podsakoff and MacKenzie (1997) demonstrated that employees who performed OCB were highly rated by their supervisors in their performance appraisal. At the level of the group, several studies found that OCB was associated positively with sales and revenue (Liu et al., 2014; MacKenzie et al., 1998; P. M. Podsakoff et al., 1997) and service performance (Lam \& Mayer, 2014). Whereas at the organizational level of analysis, OCB was positively related to organizational efficiency and flexibility (Schnake \& Hogan, 1995) and innovation (Detert et al., 2013). 
Organ (1988) defined OCB as the behaviors performed by individuals with no intention to get rewards by the organization, and organizational formal reward systems do not recognize it, but if implemented in aggregate by all employees will help improve organizational efficiency and effectiveness. Organ developed five dimensions of OCB, namely courtesy, altruism, civic virtue, sportsmanship, and conscientiousness (Organ, 1988). Williams and Anderson (1991) then simplified Organ's OCB dimensions into two dimensions, OCB-O and OCB-I. OCB-O is an individual's behaviors that are directed toward the organization to benefit the organization in general, i.e., employee compliance with organizational rules or the company in which he or she works, such as giving prior notice when they are unable to attend the organization. Organ's OCB dimensions that are part of OCB-O include conscientiousness, sportsmanship, and civic virtue. OCB-I is behaviors that are performed to benefit other individuals (such as colleagues and superiors) that help them to deliver their jobs effectively and efficiently (Williams \& Anderson, 1991). Organ's OCB dimensions that are part of OCB-I include courtesy and altruism. Examples of OCB-I are helping colleagues who are absent from work, giving advice to colleagues who need help, and assisting new employees in socializing on their work orientation. In the current study, we will only use OCB as the combined score of OCB-I and OCB-O, because we are only interested in how job attitudes affect individuals in performing OCB directed as both individuals and the organization.

Since its development, OCB researchers have investigated factors influencing $\mathrm{OCB}$, that can be organized into three motives of why individuals perform $\mathrm{OCB}$, namely prosocial values, impression management, and organizational concern (Rioux and Penner's, 2001). The prosocial value motive corresponds with an individual's consideration and cares over others, which relates to individual differences variable. Among the individual differences variable, Chiaburu, Oh, Berry, Li, and Gardner (2011) studied 87 independent research on the relationship between big five personality traits and OCB and found that neuroticism, openness to experience, and extraversion had unique variances on OCB over and above agreeableness and conscientiousness, two stable personality predictors of OCB. Impression management motive corresponds with crafting behaviors to affect others positively. This motive is driven by individual's concern over their own well-being, and when the goal is achieved, individual would lower their OCB (Halbesleben et al., 2010; Rioux \& Penner, 2001).

Meanwhile, organizational concern motive, which also corresponds with an individual's consideration and concern, is related to an individual's perception and attitude at work that drives them to certain behaviors. Among the organizational concern motive, Organ and Ryan (1995), who studied 55 studies in a meta-analysis, found that organizational commitment, job satisfaction, perceived fairness, and leader support were correlated with OCB. Recent studies on the relationship between job insecurity as a factor of OCB found that the variable may be posited either as organizational concern motive or impression management motive, depending on the levels of job insecurity (Kang et al., 2012; Lam et al., 2015; C. Lee et al., 2018; Wang et al., 2014).

Among the previously studied predictors of OCB, many studies focus on job insecurity (Kang et al., 2012; Lam et al., 2015; C. Lee et al., 2018; Schreurs et al., 2012; Wang et al., 2014). The studies found relatively inconsistent results regarding the relationship between job insecurity and OCB. Some researchers found negative relation (e.g., Cheng \& Chan, 2008; Kang et al., 2012; Stynen et al., 2015; Wong et al., 2005) wherein the feeling of insecurity about future employment in the company led to unproductive behaviors performed by the employee. Meanwhile, some studies found a positive job insecurity-OCB relationship (e.g., Feather \& Rauter, 2004; Reisel et al., 2010; Wang et al., 
2014), in which employees who feel insecure about their job show positive behaviors at work. On the other hand, another research found no association between job insecurity and OCB (Lam et al., 2015; Schreurs et al., 2012).

Job insecurity is defined as the perception of an individual about their work sustainability or longevity in the organization (Lam et al., 2015). Job insecurity is considered one of the most common stressors in organizations, particularly these days that will continue to be the significant feature of work in the future (C. Lee et al., 2018). Higher job insecurity leads to negative impacts both for individuals and organizations in the form of high job stress, high negative emotions, low job satisfaction, low OCB, and high deviant behaviors (Reisel et al., 2010). For this reason, job insecurity may belong to organizational concern motive when the levels of job insecurity are low to moderate, in which job insecurity affected OCB negatively when individuals perceive that their organization provides less security in their employment (Guzman \& Espejo, 2015; Lam et al., 2015). However, when job insecurity levels are moderate to high, impression management motive takes over, in which individuals would do anything to win over an organization's favor to keep their employees safe (Lam et al., 2015).

Social exchange theory (Blau, 1986) can explain why job insecurity negatively affects OCB (Lam et al., 2015). The fundament of social exchange theory is the reciprocity norm that creates the obligation of one party to reciprocate the other party by engaging in positive behaviors. Drawing on the social exchange theory, when individuals feel that the organization provide secure employment for them, individuals will reciprocate the organization by performing OCB. On the contrary, when individuals feel insecure about their employment continuity in the organization, they no longer feel the obligation to respond in positive behaviors, such as OCB. Based on social exchange theory, we argue that the job insecurity-OCB relationship is negative, in which individuals who are feeling insecure about their job or unable to keep their position would not be motivated to exhibit OCB because they are too busy looking for new jobs or ruminate on their situation. We are supported by results from previous studies (Cheng \& Chan, 2008; Kang et al., 2012; Stynen et al., 2015; Wong et al., 2005). Moreover, Lam et al. (2015) implied from their research that the job insecurity-OCB relationship might occur in participants who experienced job insecurity in the low to moderate score range.

As previous studies found inconsistencies in the relationship between job insecurity and OCB (Cheng \& Chan, 2008; Kang et al., 2012; Lam et al., 2015; Reisel et al., 2010; Schreurs et al., 2012; Stynen et al., 2015; Wang et al., 2014; Wong et al., 2005), an argumentation that there is a mediator in the relationship arises. Some studies have looked at other variables that might explain the relationship, such as organizational commitment and job satisfaction (see, for example, Reisel et al., 2010; Staufenbiel \& König, 2010; $\underline{\text { Stynen et }}$ al., 2015). We draw on organizational identification theory (Mael \& Ashforth, 1992) as a theoretical framework in explaining the mediating effect of affective commitment in the relationship between job insecurity and OCB. Organizational identification is an example of social identification in which employees share the same values with their organization, in that they feel that they belong to the organization (Mael \& Ashforth, 1992). Affective commitment, as one of the components of organizational commitment, corresponds with the identification theory in which individuals are willing to stay in the organization because of belongingness with the organization. The current study is not the first study to offer a mediating effect between job insecurity and OCB. Staufenbiel and König (2010) tested the mediating effect of attitudes toward work consisted of the total score of job satisfaction and organizational commitment on job insecurity-OCB relationships in Germany. However, unlike the previous study, the theoretical contribution of the current research includes directly 
testing affective commitment in particular in the relationship between job insecurity and OCB. Previous studies revealed the positive impact of affective commitment on OCB (Aslam et al., 2012; Y. H. Lee et al., 2018; Purba et al., 2015; Wei et al., 2012).

Moreover, affective commitment, along with normative commitment, was found higher in mean levels in stronger collectivist values compared to individualist values (Meyer et al., 2012). Other studies also found affective commitment to be positively related to collectivism (Felfe et al., 2008; Wasti \& Can, 2008). Since Indonesia was categorized as having high levels of collectivism (Hofstede \& Hofstede, 2005), we argue that affective commitment is an important variable that may explain attitudes and behaviors at work. Hence, we opted to investigate the effect of affective commitment rather than the total score of organizational commitment as the mediator in job insecurity - OCB relationship as previously studied (Staufenbiel \& Konig, 2010). Moreover, employee's concerns and consideration over the organization in the form of OCB will only be possible when individuals affectively committed to the organization (Guzman \& Espejo, 2015).

Affective commitment is a part of the three components of organizational commitment, coming from the willingness to be a part of the organization, proposed by Allen and Meyer (1990). Affective commitment is defined as a sense of commitment based on positive feelings of an emotional relationship, identification, and engagement with the company (Allen \& Meyer, 1990). Continuance commitment a sense of commitment based on the costs incurred if leaving the organization (time, money, effort) that keep them from leaving the organization. Normative commitment is defined as a commitment that is based on obligation and moral values individuals hold that keep them to stay in the organization. Out of the three components, researchers tend to value affective commitment most because previous studies showed that affective commitment has a higher positive impact on OCB than other types of commitment (e.g., Farzaneh et al., 2014; Ng \& Feldman, 2011; Purba et al., 2015). Besides, previous studies have shown that affective commitment has a negative relationship with job insecurity (De Cuyper et al., 2009; Huang et al., 2010; Masia \& Pienaar, 2011).

Based on organizational identification theory (Mael \& Ashforth, 1992), affective commitment may mediate the job insecurity-OCB relationship. Organizational identification theory explains that when an employee is identified with the organization, she/he will feel that the organization is a part of her/him. In this sense, the employee shares the same values and goals as the organization and will feel lost if he/she would have to leave the organization (Mael \& Ashforth, 1992). Also, employees who have identified themselves with the organization will support the organization in various ways (Mael \& Ashforth, 1992; Wu et al., 2016). On the other hand, employees who are uncertain about their employment in the organization would feel afraid and unsure, which in turn would be unable to develop positive feelings toward the organization (Tian et al., 2014). Based on this explanation, when an employee feels he/she is unable to keep the job or feel insecure about his/her work, this will negatively affect the emotional feeling and the process of identification with the organization, and in turn, will reduce the desire to perform OCB. Conversely, if an employee feels the job is safe and the employment can last longer, she/he will be emotionally attached and identified with the organization, and in turn, will be willing to perform OCB (Wu et al., 2016).

In this study, we examine the role of job insecurity as the antecedent of OCB, with affective commitment as a mediator because nowadays both permanent and contract employees are under pressure due to the competitions and lack of guarantees to be employed in organizations in longer-term (De Cuyper \& De Witte, 2007; C. Lee et al., 2018). We argue that job insecurity may be categorized as an organizational concern motive. Our argument base on our samples come from private and state-owned enterprises with clear employment 
security that may pose lower to moderate levels of job insecurity compared to small-sized and start-up companies (De Witte \& Näswall, 2003). Thus, we hypothesize that:

Hypothesis 1: There is a negative association between job insecurity and OCB

Hypothesis 2: Affective commitment mediates the job insecurity-OCB relationship.

\section{Method}

\section{Research Design}

The study employed survey research, wherein a paper-based survey was used to collect data in nine private and state-owned companies in Jakarta. The participants were ensured that the data are confidential and that the participation was anonymous and voluntary. We used temporal separation on data collection of predictors and outcome variables by two weeks, as suggested by Podsakoff et al. (2003), to reduce the potential of common method bias. Therefore, we developed some codes for participants to relate the survey one and survey two.

\section{Participants}

Participants were recruited based on two criteria: minimum one-year employment in the current organization and the willingness to participate in a two-wave survey. One-year work in the current organization should be sufficient to develop participants' affective commitment with the organization. We employed the accidental sampling method, in which we only recruited participants based on their availability during the survey. In the survey one, we sent out 300 questionnaires consists of measurement tools on job insecurity and affective commitment. Of the 300 questionnaires returned, 250 people filled the questionnaire and were willing to proceed to the second survey. Two weeks later, we sent out 250 questionnaires to measure OCB. Of the 250 surveys returned, we only used 217 questionnaires as the remaining 33 questionnaires were incomplete responses or unclear codes. The mean age of the participants was $33.3(S D=8.30)$. Table 1 showed an overview of participants' demographic data. More than half of the participants were male employees $(60.8 \%)$, and $56.2 \%$ of the participants held contract work status. Finally, almost half of the participants (47\%) had tenure of 1-5 years in the current company.

Table 1

Demographic Data of Participants $(N=217)$

\begin{tabular}{lrr}
\hline & $n$ & $\%$ \\
\hline Gender & & \\
$\quad$ Male & 132 & 60.8 \\
$\quad$ Female & 85 & 39.2 \\
Work status & & \\
$\quad$ Permanent workers & 95 & 43.8 \\
$\quad$ Contract workers & 122 & 56.2 \\
Tenure & & \\
1 to 5 years & 102 & 47.0 \\
6 to 10 years & 56 & 25.8 \\
$\quad$ Above ten years & 59 & 27.2 \\
\hline
\end{tabular}




\section{Instruments}

Three scales, OCB scale, job insecurity scale, and affective commitment scale, were translated from English to Indonesian and then back-translated from Indonesian to English by two bilingual organizational psychologists. The description of each scale as follows.

Organizational citizenship behavior. The 7-item OCBO and 7-item OCBI scales were taken from the Task Performance Scale of Williams and Anderson (1991). All items used a 5-point scale with responses from 1 (strongly disagree) to 5 (strongly agree). An example item is: "I help others who have heavy work." Coefficient $\alpha$ of OCBI and OCB scales were .85 and .75, respectively (William \& Anderson, 1991). Coefficient $\alpha$ for this study were 0.70 for OCBI and 0.64 for OCBO. Item-total correlation of the OCBI scale ranged between .30 to .52 , and the item-total correlations of the OCBO scale ranged from .29 to .46.

Job insecurity. The 11-item job insecurity questionnaire developed by De Witte (2005) and Bosman and Buitendach (2005) was used in the study. Items were rated on a 5point scale with responses from 1 (strongly disagree) to 5 (strongly agree). An example item is: "I think that I will be able to continue working here." The coefficient $\alpha$ of the job insecurity questionnaire was .84 (Busman \& Buitendach, 2005). The reliability coefficients for job insecurity scale in this study was .84 , with item-total correlation coefficients ranged from .15 to .65 .

Affective commitment. The 6-item affective commitment scale from Meyer and Allen (1997) was used. The items were rated on a 7-point scale with responses ranging from 1 (strongly disagree) to 7 (strongly agree). An example item is: "I do not feel like "part of the family' at my organization." The coefficient $\alpha$ of the affective commitment scale was .71 (Meyer \& Allen, 1997). The reliability coefficients for the affective commitment scale in this study was .71, with item-total correlation coefficients ranged range .33 to .59 .

\section{Data analysis}

We used Hayes' PROCESS macro on SPSS software (Hayes, 2017) to test affective commitment as the mediator on the job insecurity-OCB relationship. Hayes' PROCESS macro is developed to examine models using bootstrap confidence intervals to determine the level of significance of effect sizes (Hayes, 2017). This macro provides a robust method to avoid the Type II error in Baron and Kenny's (1986) method (Zhao et al., 2010).

\section{Results}

Table 2 demonstrates the descriptive statistics and inter-correlations between variables. Job insecurity negatively and significantly correlated with OCB $(r=-.17, p<.01)$. This result indicates that individuals with high job insecurity tend to have a low level of OCB. Job insecurity is negatively and significantly correlated with affective commitment $(r=-.21, p$ $<.01)$. This result suggests that individuals with high job insecurity tend to have low affective commitment. Table 2 also shows that affective commitment is positively and significantly correlated with OCB $(r=.40, p<.01)$. This result suggests that individuals with high affective commitment tend to perform high OCB. 
Table 2

Descriptive Statistics and Inter-correlation between Variables

\begin{tabular}{|c|c|c|c|c|c|c|}
\hline & Variables & $M$ & $S D$ & 1 & 2 & 3 \\
\hline 1 & Job Insecurity & 2.32 & .57 & 1 & & \\
\hline 2 & $\begin{array}{l}\text { Organizational Citizenship } \\
\text { Behavior }\end{array}$ & 3.93 & .36 & $-.17^{* *}$ & 1 & \\
\hline 3 & $\begin{array}{l}\text { Affective Organization } \\
\text { Commitment }\end{array}$ & 4.95 & .85 & $-.21^{* *}$ & $.40^{* * *}$ & 1 \\
\hline
\end{tabular}

To test the two hypotheses, we used the PROCESS macro from Hayes embedded in the SPSS software to examine the mediation effect of affective commitment on job insecurity relationship with OCB. Table 3 shows the total effect of job insecurity on OCB was significant $(c=-.11, S E=.04, p=.01)$. This result supported Hypothesis 1 that stated there was a negative association on the job insecurity-OCB relation. Moreover, job insecurity affected affective commitment negatively $(a=-.31, S E=.10, p=.002)$, and affective commitment affected OCB positively $(b=.16, S E=.027, p<.001)$. This result is in line with the results of the inter-correlation between variables.

Table 3

Affective Commitment as a Mediator on Job Insecurity-OCB Relationship

\begin{tabular}{|c|c|c|c|c|c|c|c|c|}
\hline \multirow[b]{3}{*}{ Antecedents } & & \multicolumn{7}{|c|}{ Outcomes } \\
\hline & & \multicolumn{4}{|c|}{ Affective Commitment } & \multicolumn{3}{|c|}{ OCB } \\
\hline & & Coeff. & $S E$ & $p$ & & Coeff. & $S E$ & $P$ \\
\hline \multirow[t]{2}{*}{ Job Insecurity } & $a$ & -.31 & .10 & $<.01$ & $c$ & -.11 & .04 & .01 \\
\hline & & & & & $c^{\prime}$ & -.06 & .04 & .16 \\
\hline Affective Commitment & & - & - & - & $b$ & .16 & .3 & $<.01$ \\
\hline \multirow[t]{3}{*}{ Constant } & $i_{1}$ & 5.67 & .24 & $<.01$ & $i_{2}$ & 3.26 & .18 & $<.01$ \\
\hline & & \multicolumn{4}{|c|}{$R^{2}=.42$} & \multicolumn{3}{|c|}{$R^{2}=.17$} \\
\hline & & \multicolumn{4}{|c|}{$F(1,215)=9.43 ; \mathrm{p}<.01$} & \multicolumn{3}{|c|}{$F(2,214)=22.09 ; \mathrm{p}<.01$} \\
\hline
\end{tabular}

Indirect effect $=-.05$, Boot $S E=.0211,95 \%$ CI [-.0990, -.0159]

Note. $N=217 . \mathrm{a}=$ the path from job insecurity to affective commitment. $\mathrm{b}=$ the path from the affective commitment to OCB. $c=$ total effect of job insecurity on OCB before an affective commitment was included in the model. $\mathrm{c}^{\prime}=$ direct effect of job insecurity on OCB after the affective commitment was included in the model. $i_{1}$ and $i_{2}=$ the coefficients of constant on affective commitment and OCB.

Table 3 showed that affective commitment significantly mediated the relationship between job insecurity and OCB. Hypothesis 2 posited the mediating effect of affective commitment in the relation of job insecurity and OCB. Results showed a significant indirect effect (Indirect effect $=-.05$, Boot SE $=.0211,95 \%$ CI [-.0990, -.0159]), supporting our Hypothesis 2. The direct effect of job insecurity on OCB became non-significant ( $c^{\prime}=-.06$, $S E=.040, p=.163$ ), indicating that affective commitment plays a significant role to mediate the job insecurity-OCB relationship. Figure 1 showed the research model depicted relationships between the variables. 


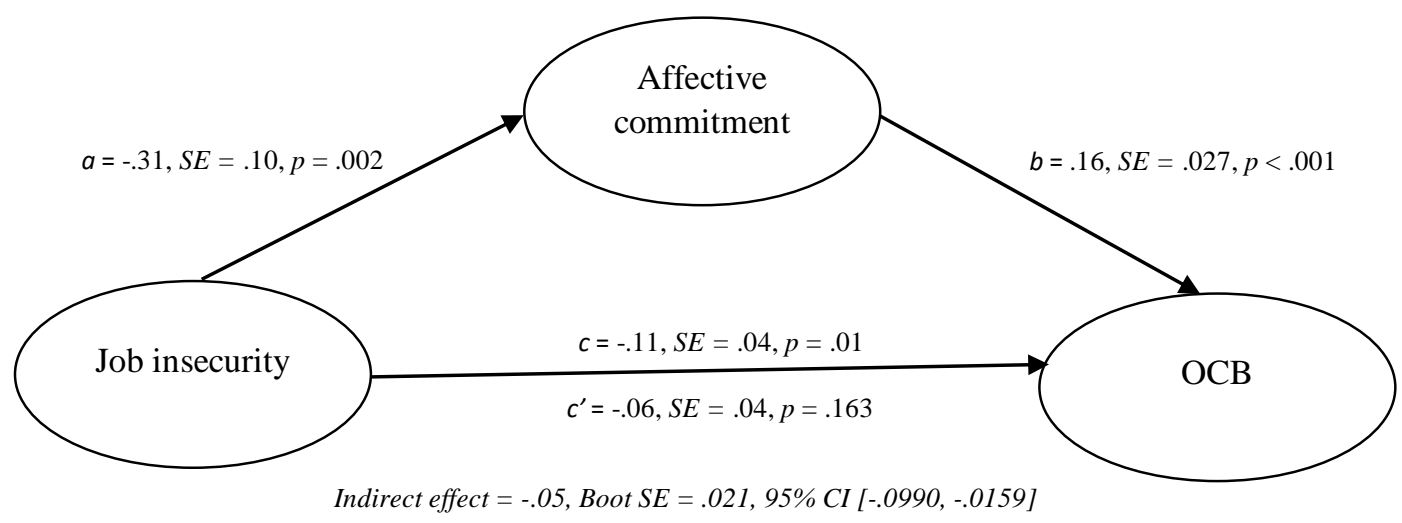

Figure 1. Research model on the mediating effect of affective commitment

\section{Discussion}

This study investigated the relationship between job insecurity and OCB, with the mediating effect of affective commitment. Our findings support the first hypothesis that states job insecurity is negatively related to OCB. The results indicate that when one feels insecure with the work, one will decrease the willingness to perform OCB. According to the motive theory of OCB (Rioux \& Penner, 2001), this result is in line with the organizational concern motive. Individuals with high insecurity over their employment status tend to be unable to develop concern over the organization's well-being, which leads to lower helping behaviors (OCBs) in the organization. The results confirm previous studies that found a negative relationship between job insecurity and OCB (Cheng \& Chan, 2008; Kang et al., 2012; Reisel et al., 2010).

Our finding shows a negative relationship between job insecurity and affective commitment. Job insecurity implies powerlessness in which individuals who perceive that their employment in the organization would not last longer tend to feel afraid and uncertain about their situation (Tian et al., 2014). The negative feelings imposed by the uncertainty in their employment status would then lead to low levels of affective commitment toward the organization. This finding is in line with organizational identification theory, which explains that when an individual feels uncertain about their employment in the organization, one will feel afraid and insecure, and unable to develop positive feelings toward the organization. The situation will negatively affect the process of identification with the organization. Thus the individual will be unable to create "oneness" with the organization, or in other words, affective commitment toward the organization (Mael \& Ashforth, 1992). This result supports the results of previous research (De Cuyper et al., 2009; Tian et al., 2014).

Our findings also show a positive relationship between affective commitments with OCB. Affective commitment is one of the positive organizational behavior variables that are related to positive outcomes such as job performance and OCB (Meyer et al., 2012). Individuals high in affective commitment tend to have positive feelings toward the organization and develop an identification with the organization. Because of their identification and positive emotional attachment with the organization, individuals would, in turn, engage in higher OCB by helping other members of the organization and protect the organization's good image. This result is in line with previous studies (Farzaneh et al., 2014; Feather \& Rauter, 2004; Purba et al., 2015).

Finally, the results show that affective commitment plays a significant role as a mediator in the relationship between job insecurity and OCB. These results indicate that 
individuals who feel that their employment is threatened tend to have a low emotional attachment with the organization and little identification with the organization. Lack of positive affect toward the organization is an indication of low affective commitment. This condition will, in turn, lower the willingness to perform OCB. In a way, our study is a replication of Staufenbiel and König's (2010) study in Germany, who tested the mediating effect of attitude toward work, consisted of organizational commitment and job satisfaction variables, on job insecurity - OCB relationship on 136 German employees. We found that our findings were in line with Staufenbiel and König's (2010) findings. However, their study did not directly test affective commitment as the mediator on job insecurity - OCB relationship. They tested the mediating effect of attitudes toward work, in which they measured the variable as a total score of organizational commitment and job satisfaction constructs. Thus, our contribution is to examine affective commitment as an independent work attitude variable as a mediating effect in a collectivist country (Hofstede \& Hofstede, 2005). In which affective commitment is regarded as an essential variable that affects positive outcomes in a collectivist society (Farzaneh et al., 2014; Kartika \& Purba, 2018; Purba et al., 2015).

A theoretical contribution of this study is that this study demonstrates affective commitment as a robust mediator in the job insecurity-OCB relationship. Most research on job insecurity-OCB relation employs social exchange theory (Blau, 1986) as their framework theory (Lam et al., 2015), in which individuals decide to reciprocate positively toward the organization whenever the organization supports them at work. In contrast, when the organization does not support them, employees do not have an obligation to perform positive work behaviors such as OCB. However, given the collectivist nature of Indonesia, organizational identification theory (Mael \& Ashforth, 1992) would be more appropriate to explain why high job insecurity leads to low OCB compared to social exchange theory ( $\mathrm{Wu}$ et al., 2016). Individuals in collectivist countries tend to have strong social ties and value ingroup goals compared to individualist countries (Meyer et al., 2012). Thus, in a collectivist society, positive identification with a group is a requirement to engage inappropriate behaviors that suit the group (Mael \& Ashforth, 1992). In this vein, developing identification with the organization is essential so that employees can perform positive work behaviors. High levels of job insecurity may deplete their energy and trust toward the organization that leads to low levels of affective commitment because employees do not feel the "oneness" with the organization and that in turn leads to lower OCB. However, we did not directly examine the collectivism in this study. Thus, we suggest future studies to include individualist-collectivist value as a moderator variable, as we propose that collectivist value may elevate the mediating role of affective commitment in job insecurity-OCB relationship. We just assume that job insecurity poses lack of organizational concern rather than impression management motive in this study. Thus, we suggest future studies to examine when and how job insecurity positively related to OCB, enacting the impression management motive hypothesis.

There are limitations in this study. First, the correlational design affects the power analysis, and in turn, affects the ability to establish the causal relationship between variables. To overcome this problem, we suggest future research to use longitudinal study to examine variations of job insecurity, affective commitment, and OCB over time. It is also possible that these variables change with time. Second, although we argue that job insecurity is a concern for employees, either they hold permanent or contract status because of the increased competition in the labor market, we argue that our participants had low to moderate levels of job insecurity as Lam et al. (2015) contended that participants with higher job insecurity might likely to show higher OCB as a way to impress the management. It is valuable to 
examine employees working in organizations that are facing significant changes, such as mergers, downsizing, and acquisition, as employees with these situations may likely have higher levels of job insecurity. Lastly, all variables were measured using self-report measures, increasing common method variance issues. To overcome the problem, we used temporal separation in which we measured predictors and outcome variables separately. However, we suggest future research to use other robust methods such as the supervisor's assessment of OCB to overcome the biases.

\section{Conclusion}

Job insecurity as a situational factor may imply two motives of $\mathrm{OCB}$, as organizational concern or as impression management motives. In this study, we posited job insecurity as an antecedent of the lack of organizational concern motive that negatively related to OCB. Hence, based on the organizational identification theory, affective commitment is found to be a robust mediator in the job insecurity-OCB relationship. One of the managerial implications of our study is that to enable employees to identify with the organization, and managers should eliminate job insecurity where it is possible and design intervention programs to enhance employee's levels of affective commitment. For instance, organizations could identify specific job features and organizational conducts that are problematic and serve as the cause of job insecurity. These programs may reduce job insecurity, increase affective commitment, thus increase employee's OCB.

\section{References}

Allen, N. J., \& Meyer, J. P. (1990). The measurement and antecedents of affective, continuance and normative commitment to the organization. Journal of Occupational Psychology, 63(1), 1-18. https://doi.org/10.1111/j.2044-8325.1990.tb00506.x

Aslam, M. S., Ahmad, F., \& Anwar, S. (2012). Job burnout and organizational citizenship behaviors: Mediating role of affective commitment. Journal of Basic and Applied Scientific Research, 2(8), 8120-8129.

Baron, R. M., \& Kenny, D. A. (1986). The moderator-mediator variable distinction in social psychological research: Conceptual, strategic, and statistical considerations. Journal of Personality and Social Psychology, 51(6), 1173-1182.

Blau, P. (1986). Exchange and power in social life (2nd ed.). Routledge.

Bosman, J., \& Buitendach, J. H. (2005). Work locus of control and dispositional optimism as antecedents to job insecurity. SA Journal of Industrial Psychology, 31(4), 17-23. https://doi.org/https://hdl.handle.net/10520/EJC89071

Cheng, G. H., \& Chan, D. K. (2008). Who suffers more from job insecurity? A meta-analytic review. Applied Psychology, 57(2), 272-303. https://doi.org/10.1111/j.14640597.2007.00312.x

Chiaburu, D. S., Oh, I.-S., Berry, C. M., Li, N., \& Gardner, R. G. (2011). The five-factor model of personality traits and organizational citizenship behaviors: A meta-analysis. Journal of Applied Psychology, 96(6), 1140-1166. https://doi.org/10.1037/a0024004 
De Cuyper, N., \& De Witte, H. (2007). Job insecurity in temporary versus permanent workers: Associations with attitudes, well-being, and behaviour. Work \& Stress, 21(1), 65-84. https://doi.org/10.1080/02678370701229050

De Cuyper, N., Notelaers, G., \& De Witte, H. (2009). Job insecurity and employability in fixed-term contractors, agency workers, and permanent workers: Associations with job satisfaction and affective organizational commitment. Journal of Occupational Health Psychology, 14(2), 193-205. https://doi.org/10.1037/a0014603.

De Witte, H. (2005). Job insecurity: Review of the international literature on definitions, prevalence, antecedents and consequences. SA Journal of Industrial Psychology, 31(4), 1-6. https://hdl.handle.net/10520/EJC89073

De Witte, H., \& Näswall, K. (2003). ‘Objective'vs. 'Subjective’job insecurity: Consequences of temporary work for job satisfaction and organizational commitment in four European countries. Economic and Industrial Democracy, 24(2), 149-188. https://doi.org/10.1177/0143831X03024002002

Detert, J. R., Burris, E. R., Harrison, D. A., \& Martin, S. R. (2013). Voice flows to and around leaders: Understanding when units are helped or hurt by employee voice. Administrative Science Quarterly, 58(4), 624-668. https://doi.org/10.1177/0001839213510151

Farzaneh, J., Dehghanpour Farashah, A., \& Kazemi, M. (2014). The impact of person-job fit and person-organization fit on OCB: The mediating and moderating effects of organizational commitment and psychological empowerment. Personnel Review, 43(5), 672-691. https://doi.org/10.1108/PR-07-2013-0118

Feather, N. T., \& Rauter, K. A. (2004). Organizational citizenship behaviours in relation to job status, job insecurity, organizational commitment and identification, job satisfaction and work values. Journal of Occupational and Organizational Psychology, 77(1), 8194. https://doi.org/10.1348/096317904322915928

Felfe, J., Yan, W., \& Six, B. (2008). The impact of individual collectivism on commitment and its influence on organizational citizenship behaviour and turnover in three countries. International Journal of Cross Cultural Management, 8(2), 211-237. https://doi.org/10.1177/1470595808091790

Guzman, F. A., \& Espejo, A. (2015). Dispositional and situational differences in motives to engage in citizenship behavior. Journal of Business Research, 68(2), 208-215. https://doi.org/10.1016/j.jbusres.2014.09.029

Halbesleben, J. R. B., Bowler, W. M., Bolino, M. C., \& Turnley, W. H. (2010). Organizational concern, prosocial values, or impression management? How supervisors attribute motives to organizational citizenship behavior. Journal of Applied Social Psychology, 40(6), 1450-1489. https://doi.org/10.1111/j.1559-1816.2010.00625.x

Hayes, A. F. (2017). Introduction to mediation, moderation, and conditional process analysis: A regression-based approach. Guilford Publications.

Hofstede, G., \& Hofstede, G. J. (2005). Cultures and organizations: Software of the mind, revised and expanded (2nd ed., Vol. 2). McGraw-Hill.

Huang, G.-H., Lee, C., Ashford, S., Chen, Z., \& Ren, X. (2010). Affective job insecurity: A 
mediator of cognitive job insecurity and employee outcomes relationships. International Studies of Management \& Organization, 40(1), 20-39. https://doi.org/10.2753/IMO0020-8825400102

Kang, D., Gold, J., \& Kim, D. (2012). Responses to job insecurity: The impact on discretionary extra-role and impression management behaviors and the moderating role of employability. Career Development International, 17(4), 314-332. https://doi.org/10.1108/13620431211255815

Kartika, G., \& Purba, D. E. (2018). Job satisfaction and turnover intention: The mediating effect of affective commitment. Psychological Research on Urban Society, 1(2), 100106. https://doi.org/10.7454/proust.v1i2.34

Lam, C. F., Liang, J., Ashford, S. J., \& Lee, C. (2015). Job insecurity and organizational citizenship behavior: Exploring curvilinear and moderated relationships. Journal of Applied Psychology, 100(2), 499-510. https://doi.org/10.1037/a0038659

Lam, C. F., \& Mayer, D. M. (2014). When do employees speak up for their customers? A model of voice in a customer service context. Personnel Psychology, 67(3), 637-666. https://doi.org/10.1111/peps.12050

Lee, C., Huang, G.-H., \& Ashford, S. J. (2018). Job insecurity and the changing workplace: recent developments and the future trends in job insecurity research. Annual Review of Organizational Psychology and Organizational Behavior, 5(1), 335-359. https://doi.org/10.1146/annurev-orgpsych-032117-104651

Lee, Y. H., Woo, B., \& Kim, Y. (2018). Transformational leadership and organizational citizenship behavior: Mediating role of affective commitment. International Journal of Sports Science \& Coaching, 13(3), 373-382. https://doi.org/10.1177/1747954117725286

Liu, W., Gong, Y., \& Liu, J. (2014). When do business units benefit more from collective citizenship behavior of management teams? An upper echelons perspective. Journal of Applied Psychology, 99(3), 523-534. https://doi.org/10.1037/a0035538

MacKenzie, S. B., Podsakoff, P. M., \& Ahearne, M. (1998). Some possible antecedents and consequences of in-role and extra-role salesperson performance. Journal of Marketing, 62(3), 87-98. https://doi.org/10.1177/002224299806200306

Mael, F., \& Ashforth, B. E. (1992). Alumni and their alma mater: A partial test of the reformulated model of organizational identification. Journal of Organizational Behavior, 13(2), 103-123. https://doi.org/10.1002/job.4030130202

Masia, U., \& Pienaar, J. (2011). Unravelling safety compliance in the mining industry: examining the role of work stress, job insecurity, satisfaction and commitment as antecedents. SA Journal of Industrial Psychology, 37(1), 1-10. https://doi.org/10.1402/ sajip.v37i1.937

Meyer, J. P., \& Allen, N. J. (1997). Commitment in the workplace: Theory, research, and application. Sage.

Meyer, J. P., Stanley, D. J., Jackson, T. A., McInnis, K. J., Maltin, E. R., \& Sheppard, L. (2012). Affective, normative, and continuance commitment levels across cultures: A meta-analysis. Journal of Vocational Behavior, 80(2), 225-245. 
https://doi.org/10.1016/j.jvb.2011.09.005

Ng, T. W. H., \& Feldman, D. C. (2011). Affective organizational commitment and citizenship behavior: Linear and non-linear moderating effects of organizational tenure. Journal of Vocational Behavior, 79(2), 528-537. https://doi.org/10.1016/j.jvb.2011.03.006

Organ, D. W. (1988). Organizational citizenship behavior: The good soldier syndrome. Lexington Books/DC Heath and Com.

Organ, D. W., Podsakoff, P. M., \& MacKenzie, S. B. (2005). Organizational citizenship behavior: Its nature, antecedents, and consequences. Sage Publications.

Organ, D. W., \& Ryan, K. (1995). A meta-analytic review of attitudinal and dispositional predictors of organizational citizenship behavior. Personnel Psychology, 48(4), 775802. https://doi.org/10.1111/j.1744-6570.1995.tb01781.x

Podsakoff, N. P., Whiting, S. W., Podsakoff, P. M., \& Blume, B. D. (2009). Individual-and organizational-level consequences of organizational citizenship behaviors: A metaanalysis. Journal of Applied Psychology, 94(1), 122-141. https://doi.org/10.1037/a0013079

Podsakoff, P. M., Ahearne, M., \& MacKenzie, S. B. (1997). Organizational citizenship behavior and the quantity and quality of work group performance. Journal of Applied Psychology, 82(2), 262-270. https://doi.org/10.1037/0021-9010.82.2.262

Podsakoff, P. M., \& MacKenzie, S. B. (1997). Impact of organizational citizenship behavior on organizational performance: A review and suggestion for future research. Human Performance, 10(2), 133-151. https://doi.org/10.1207/s15327043hup1002_5

Podsakoff, P. M., MacKenzie, S. B., Lee, J.-Y., \& Podsakoff, N. P. (2003). Common method biases in behavioral research: A critical review of the literature and recommended remedies. Journal of Applied Psychology, 88(5), 879-903. https://doi.org/10.1037/0021-9010.88.5.879.

Purba, D. E., Oostrom, J. K., Van Der Molen, H. T., \& Born, M. P. (2015). Personality and organizational citizenship behavior in Indonesia: The mediating effect of affective commitment. Asian Business and Management, 14(2).147-170. https://doi.org/10.1057/abm.2014.20

Reisel, W. D., Probst, T. M., Chia, S.-L., Maloles, C. M., \& König, C. J. (2010). The effects of job insecurity on job satisfaction, organizational citizenship behavior, deviant behavior, and negative emotions of employees. International Studies of Management \& Organization, 40(1), 74-91. https://doi.org/10.2753/IMO0020-8825400105

Rioux, S. M., \& Penner, L. A. (2001). The causes of organizational citizenship behavior: a motivational analysis. Journal of Applied Psychology, 86(6), 1306-1314. https://doi.org/10.1037//0021-9010.86.6.1306

Schnake, M., \& Hogan, E. (1995). Organizational citizenship behavior and organizational effectiveness. Southern Management Association Proceedings. Georgia: Southern Management Association, 93-97.

Schreurs, B. H. J., Hetty van Emmerik, I. J., Günter, H., \& Germeys, F. (2012). A weekly diary study on the buffering role of social support in the relationship between job 
insecurity and employee performance. Human Resource Management, 51(2), 259-279. https://doi.org/10.1002/hrm.21465

Staufenbiel, T., \& König, C. J. (2010). A model for the effects of job insecurity on performance, turnover intention, and absenteeism. Journal of Occupational and Organizational Psychology, 83(1), 101-117. https://doi.org/10.1348/096317908X401912

Stynen, D., Forrier, A., Sels, L., \& De Witte, H. (2015). The relationship between qualitative job insecurity and OCB: Differences across age groups. Economic and Industrial Democracy, 36(3), 383-405. https://doi.org/10.1177/0143831X13510326

Tian, Q., Zhang, L., \& Zou, W. (2014). Job insecurity and counterproductive behavior of casino dealers--the mediating role of affective commitment and moderating role of supervisor support. International Journal of Hospitality Management, 40, 29-36. https://doi.org/10.1016/j.ijhm.2014.03.005

Wang, H., Lu, C., \& Lu, L. (2014). Do people with traditional values suffer more from job insecurity? The moderating effects of traditionality. European Journal of Work and Organizational Psychology, 23(1), 107-117. https://doi.org/10.1080/1359432X.2012.712751

Wasti, S. A., \& Can, Ö. (2008). Affective and normative commitment to organization, supervisor, and coworkers: Do collectivist values matter? Journal of Vocational Behavior, 73(3), 404-413. https://doi.org/10.1016/j.jvb.2008.08.003

Wei, Z., Mian, Z., \& Hai, L. (2012). Performance appraisal process and organizational citizenship behavior. Journal of Managerial Psychology, 27(7), 732-752. https://doi.org/10.1108/02683941211259548

Williams, L. J., \& Anderson, S. E. (1991). Job satisfaction and organizational commitment as predictors of organizational citizenship and in-role behaviors. Journal of Management, 17(3), 601-617. https://doi.org/10.1177/014920639101700305

Wong, Y.-T., Wong, C.-S., Ngo, H.-Y., \& Lui, H.-K. (2005). Different responses to job insecurity of Chinese workers in joint ventures and state-owned enterprises. Human Relations, 58(11), 1391-1418. https://doi.org/10.1177/0018726705060243

Wu, C.-H., Liu, J., Kwan, H. K., \& Lee, C. (2016). Why and when workplace ostracism inhibits organizational citizenship behaviors: An organizational identification perspective. Journal of Applied Psychology, 101(3), 362-378. https://doi.org/10.1037/ap10000063

Zhao, X., Lynch Jr, J. G., \& Chen, Q. (2010). Reconsidering Baron and Kenny: Myths and truths about mediation analysis. Journal of Consumer Research, 37(2), 197-206. https://doi.org/10.1086/651257 